ВИМОГИ СУЧАСНИХ МЕТОДОЛОГІЧНИХ ПІДХОДІВ

ДО ОРГАНІЗАЦІЙНО-ПЕДАГОГІЧНИХ УМОВ РОЗВИТКУ

ПРОФЕСІЙНОÏ КОМПЕТЕНТНОСТІ ОРГАНІЗАТОРІВ

МОРАЛЬНО-ПСИХОЛОГІЧНОГО ЗАБЕЗПЕЧЕННЯ

\title{
REQUIREMENTS OF MODERN METHODOLOGICAL APPROACHES \\ TO ORGANIZATIONAL AND PEDAGOGICAL CONDITIONS \\ OF PROFESSIONAL COMPETENCE DEVELOPMENT OF ORGANIZERSOF MORAL AND PSYCHOLOGICAL SUPPORT
}

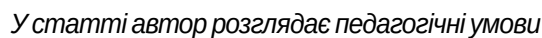
розвитку професійної компетентності організаторів морально-психологічного забезпечення. Для з'ясування даних умов розвитку профресійної компетентності організаторів морально-психологічного забезпечення автор вивчає такі методологічні підходи до організації підвищення їхньої педагогічної кваліфрікації, як системний, компетентнісний, суб'єктно-діяльнісний підходи, а також дослідження вказаних підходів провідними вченими. Аналіз наукових підходів до визначення поняття «організаційно-педагогічні умови» дав змогу зробити висновок про те, що під організаційно-педагогічними умовами розвитку професійної компетентності організаторів морально-психологічного забезпечення варто розуміти сукупність необхідних і достатніх системних організаційних і педагогічних обставин і чинників у системі післядипломної освіти (на етапі оперативно-тактичної підготовки в Національному університеті оборони України імені Івана Черняховського), які забезпечують найбільш сприятливе педагогічне середовище для розвитку профресійної компетентності організаторів морально-психологічного забезпечення в системі післядипломної освіти.
\end{abstract}

У статmі, на основі аналізу психолого-педагогічної літератури, уточнюється методика розвитку профессійної компетентності в організаторів морально-психологічного забезпечення. Вона розглядається як система науково обгрунтованих правил і прийомів навчання. Автор також зазначає, що кончепція дослідження забезпечується єдністю теоретичного, методологічного та методичного аспектів.

Проблема розвитку просресійної компетентності організаторів морально-психологічного забезпечення багато в чому залежить від успішного фрункціонування як цілої педагогічної системи, так і всіх ї̈ елементів, у зв'язку із чим необхідний розгляд саме організаційно-педагогічних умов. Також автор визначає педагогічні умови, які доцільно цілеспрямовано створювати та підтримувати для педагогічного забезпечення системного розвитку професійної компетентності організаторів морально-психологічного забезпечення.

Ключові слова: морально-психологічне забезпечення, профресійна компетентність, організатори морально-психологічного забезпечення, організаційно-педа- гогічні умови розвитку, системний підхід, суб'єктно-діяльнісний підхід, методологічний підхід.

The article deals with the pedagogical conditions of professional competence development of organizers of moral and psychological support. To find out these conditions for the development of professional competence of the organizers of moral and psychological support, the author considers such methodological approaches to the organization of improving their pedagogical qualifications as systemic, competent, subjectactivity approaches, as well as research of leading scientists of these approaches. The analysis of scientific approaches to the definition of the term "organizational and pedagogical conditions" has made it possible to conclude that under the organizational and pedagogical conditions of the professional competence of the organizers of moral and psychological support should be understood the set of necessary and sufficient systemic organizational and pedagogical circumstances and factors in the system of postgraduate education that provide the most favorable pedagogical environment for the development of professional competence of moral and psychological support organizers in the system of postgraduate education

In the article, on the basis of the analysis of the psychological and pedagogical literature, the methodology of professional competence development among the organizers of moral and psychological support is specified. It is considered as a system of science-based rules and techniques of training. It is also noted that the concept of research is ensured by the unity of theoretical, methodological and methodic aspects. The problem of development of professional competence of the organizers of moral and psychological support largely depends on the successful functioning of both the whole pedagogical system and all its elements, in connection with what it is necessary to consider the organizational and pedagogical conditions. The author also defines the pedagogical conditions that it is expedient to create and maintain for the pedagogical support of the systemic development of the professional competence of the organizers of moral and psychological support.

Key words: moral and psychological support, professional competence, organizers of moral and psychological support, organizational and pedagogical conditions of development, systematic approach, subject-activity approach, methodological approach.
Національного університету оборони

України імені Івана Черняховського
Постановка проблеми в загальному вигляді. Розв'язання проблеми підвищення якості професійної підготовленості організаторів морально-пси- хологічного забезпечення передбачає вдосконалення військово-професійної підготовки в напрямі цілеспрямованого розвитку в них профресійної 
компетентності в системі післядипломної освіти на основі реалізації вимог сучасних методологічних підходів до підвищення їхньої фрахової квалісрікації.

Аналіз останніх досліджень і публікацій. Для обґрунтування методологічних підходів до розвитку професійної компетентності організаторів морально-психологічного забезпечення важливі результати наукових досліджень В. Андрущенка, Е. Зеєра, А. Зельницького, І. Зимньої, І. Зязюна, Н. Кузьміної, В. Кременя, В. Лутая, Н. Ничкало, В. Ортинського, Е. Юдіна, В. Ягупова й ін., у яких містяться сучасні методологічні вимоги до професійної підготовки фрахівців.

Мета статті - 3'ясувати педагогічні умови розвитку професійної компетентності організаторів морально-психологічного забезпечення.

Виклад основного матеріалу. У «Філософрському енциклопедичному словнику» поняття «методологія» тлумачиться як сукупність підходів, способів, методів, прийомів і процедур, що застосовується у процесі наукового пізнання та практичної діяльності для досягнення наперед визначеної мети [21, с. 374].

У наукових працях поняття «підхід» тлумачиться як сукупність взаємопов'язаних ідей, принципів і методів, які покладені в основу розв'язання певних проблем [21]. Методологічні підходи до розвитку профресійної компетентності організаторів морально-психологічного забезпечення (далі МПЗ), що застосовуються в педагогічній теорії і практиці, свідчать про багатоаспектність цієї проблеми. Зокрема, дослідники для вирішення педагогічних проблем застосовують різні методологічні підходи (табл. 1).

Таке досить широке розмаїття методологічних підходів дає змогу дослідникам обирати той чи інший підхід, хоча найчастіше вчені у своїх дослідженнях спираються на сукупність декількох таких підходів. До таких підходів, що найбільше відповідають вимогам ефективного розвитку профресійної компетентності організаторів морально-психологічного забезпечення в системі післядипломної освіти, ми віднесли: системний, компетентнісний, контекстний і суб'єктно-діяльнісний. Кожен із цих підходів має методологічну цінність. Проте для нашого дослідження особливо суттєві суб'єктнодіяльнісний і компетентнісний підходи, що дають можливість системно усвідомити та сприймати цілеспрямовану підготовку фрахівців МПЗ, проникнути в суть структури їхньої профресійної компетентності. Але найголовніше те, що ці підходи мають застосуватися системно в контексті їхньої майбутньої військово-професійної діяльності. Так, у фрілософрії поняття «система» розуміється як «сукупність елементів, що перебувають у відношеннях і зв'язках один 3 одним, утворюючи певну цілість, єдність» [22, с. 610]. А поняття «системний підхід» означає загальнонаукову методологічну концепцію, особливу стратегію наукового пізнання і практичної діяльності, яка орієнтує науковців на дослідження складних об'єктів як систем $[21$, с. 584].

Системний підхід у розвитку професійної компетентності організаторів морально-психологічного забезпечення використовуємо в контексті педагогічної системи, що створена в системі післядипломної освіти для розвитку складових частин їхньої профресійної компетентності, оскільки системний підхід передбачає дотримання чітких методологічних принципів, які забезпечують системну спрямованість її розвитку. Це принципи цілісності, примату цілого над його складовими частинами,

Таблиця 1

Методологічні підходи до розв'язання педагогічних проблем

\begin{tabular}{|c|c|c|c|}
\hline $\begin{array}{l}\text { № } \\
3 / \Pi\end{array}$ & Автори & Педагогічні проблеми & Методологічні підходи \\
\hline 1. & $\begin{array}{l}\text { О. Вознюк, } \\
\text { О. Дубасенюк }\end{array}$ & $\begin{array}{c}\text { обґрунтування } \\
\text { компетентнісного підходу } \\
\text { в освіті }\end{array}$ & $\begin{array}{l}\text { акме-цільовий; розвивальний; стратегічно орієнтований; } \\
\text { профресіографрічний; задачно-ситуативний; технологічний; } \\
\text { рефрлексивний; подійний; історико-логічний; коеволюційно- } \\
\text { ноосферний; стимульно-інформаційно-ресурсний; приро- } \\
\text { довідповідно-диференційований; діалоговий; амбівалент- } \\
\text { ний; критико-конструктивний; діяльнісно-праксеологічний, } \\
\text { суб'єктно-діяльнісний, контекстний; особистісно орієнто- } \\
\text { ваний; суб'єкт-суб'єктний; партисипативно-інтерактивний; } \\
\text { суб'єктний; наративний; герменевтичний; фрілософрсько- } \\
\text { антропологічний; ффундаменталізаційний; системно-синер- } \\
\text { гетичний; інтегративний; цивілізаційно-середовищний; } \\
\text { нормативно-аксіологічний; культурологічний [17, с. 11-18]; }\end{array}$ \\
\hline 2. & М. Михнюк & $\begin{array}{c}\text { розвиток професійної } \\
\text { культури викладачів спе- } \\
\text { ціальних дисциплін }\end{array}$ & $\begin{array}{c}\text { культурологічний; аксіологічний; компетентнісний; діяльніс- } \\
\text { ний; системний; креативний; особистісно орієнтований } \\
{[12, \text { с. } 20] ;}\end{array}$ \\
\hline 3. & $\begin{array}{l}\text { А. Вітченко, } \\
\text { В. Осьодло }\end{array}$ & $\begin{array}{c}\text { методологічне підґрунтя } \\
\text { сучасної університетської } \\
\text { освіти }\end{array}$ & $\begin{array}{c}\text { окремі фрілософрські ідеї прагматизму, критичного раціона- } \\
\text { лізму, екзистенціалізму, герменевтики, а також синергетика, } \\
\text { аксіологія, акмеологія [4, с. 137-138]; }\end{array}$ \\
\hline 4. & В. Ягупов & $\begin{array}{c}\text { Методологічні засади } \\
\text { підготовки фрахівців }\end{array}$ & $\begin{array}{c}\text { компетентнісний; діяльнісний; системний; суб'єктно- } \\
\text { діяльнісний [26]. }\end{array}$ \\
\hline
\end{tabular}


ієрархічності та полісистемності [21, с. 584], реалізація яких забезпечує, з одного боку, цілісність розвитку професійної компетентності організаторів морально-психологічного забезпечення, а з іншого - стосується всіх компонентів їхньої компетентності.

Система розвитку професійної компетентності організаторів морально-психологічного забезпечення має характеризуватися цілісністю та єдністю закономірно взаємопов'язаних і взаємозумовлених елементів і відповідати таким класичним ії ознакам, як: наявність найпростіших одиниць - елементів, що входять до їі складу (вищі військові навчальні заклади); наявність підсистем - результатів взаємодії елементів, яка виражається через відповідну структуру й ієрархічність, тобто підготовка фрахівців МПЗ здійснюється поступово від тактичної ланки до стратегічної; наявність компонентів - результатів взаємодії підсистем, тобто фаховий і професійний розвиток фрахівців МПЗ; наявність внутрішньої структури зв'язків між цими компонентами, а також їхніми підсистемами, що має загальну мету щодо забезпечення постійного профеесійного та фрахового зростання фрахівців МП3; наявність певного рівня цілісності, ознакою якого $є$ те, що система розвитку професійної компетентності організаторів морально-психологічного забезпечення завдяки взаємодії компонентів отримує результат, який задовольнить як замовника, так і випускника фрахівця МПЗ; наявність у структурі системостворювальних зв'язків, які об'єднують компоненти і підсистеми як частини в єдину систему та забезпечують безперервність її фрункціонування, тобто розвиненість професійної та фахової компетентностей організаторів морально-психологічного забезпечення; зв'язок з іншими системами зовнішнього середовища - системами військової освіти та підготовки фрахівців МПЗ [28].

Отже, системний підхід надає можливість результативно розвивати профресійну та, найголовніше, фрахову компетентності фрахівців МПЗ, чітко визначати пріоритетні напрями їхнього фрахового розвитку, структурувати його зміст, здійснювати безперервне вдосконалення профресійної діяльності щодо підвищення кваліфікації фрахівців МПЗ.

Велике значення для розвитку професійної та фрахової компетентностей фрахівців МПЗ має контекстний підхід, основні вимоги якого відображено в основному в наукових працях А. Вербицького та представників його наукової школи. Так, контекстним $€$ таке навчання, у якому мовою науки і за допомогою всієї системи традиційних і сучасних форм, методів і засобів навчання послідовно моделюється та реалізується предметний і соціальний зміст майбутньої професійної діяльності тих, хто вчиться [3, с. 53]. На основі узагальнення їхніх наукових напрацювань можна ссрормулювати такі принципи контекстного підходу до підго- товки фрахівців МПЗ: педагогічного забезпечення особистісного включення того, хто здобуває певну освіту, у навчальну діяльність як її суб'єкта; моделювання в навчальній діяльності того, хто вчиться, цілісного змісту, форм і умов його майбутньої професійної діяльності - МП3; проблемного змісту професійного навчання та фрахової підготовки; адекватності організації навчальної діяльності тих, хто вчиться, цілям, змісту та специфріці майбутньої професійної та фрахової діяльності; провідної ролі спільної діяльності, міжособистісного спілкування та взаємодії суб'єктів навчання - педагогів і тих, хто вчиться; педагогічно обґрунтованого співвідношення нових і традиційних педагогічних технологій, методик і засобів професійної підготовки, наприклад, імітаційного моделювання, IKT; забезпечення єдності навчання, виховання, розвитку, самовдосконалення особистості фахівця. Найголовніша ідея - це стимулювання квазіпрофесійної та навчально-професійної діяльності слухачів у навчанні.

Отже, контекстне навчання організаторів МПЗ потребує моделювання, за допомогою предметного і соціального змісту, їхньої майбутньої військово-педагогічної діяльності в системі післядипломної освіти. Оскільки контекстний підхід зорієнтований на професійну діяльність слухача, то можемо констатувати його безпосередній зв'язок із компетентнісним і суб'єктно-діяльнісним методологічними підходами, оскільки компетентно має діяти офіцер у військово-професійній діяльності.

Провідне значення для нашого дослідження має компетентнісний підхід, оскільки професійна компетентність організаторів МПЗ $є$ інтегрованою системою окремих видів військово-професійної компетентності, серцевину якої становить їхня фрахова компетентність як організаторів МПЗ. Проблема впровадження компетентнісного підходу в систему вищої освіти є предметом досліджень І. Зязюна, Н. Ничкало, Н. Кузьміної, В. Сластьоніна, В. Беспалька, О. Дубасенюк, О. Ломакіної та ін. Різні аспекти розвитку компетентності у своїх працях розглядали Е. Зеєр, І. Зимня, В. Ягупов та iн. Вони, зокрема, наголошують на можливості підвищення якості освіти у вищій школі та забезпеченні конкурентоспроможності випускників завдяки впровадженню компетентнісного підходу у вищу освіту.

Тлумачення поняття «компетентнісний підхід» $\mathrm{i}$ досі $є$ предметом дискусій у педагогічній теорії та практиці. Він передбачає наявність комплексу цінностей, мотивації, умінь, здатностей, професійно важливих якостей фрахівця розв'язувати певні проблеми [26, с. 48].

Проаналізувавши суть компетентнісного підходу та погляди науковців щодо його реалізації, В. Ягупов визначив, що він покликаний сприяти забезпеченню «взаєморозуміння», «взаємодії» 
та «координації» компетенцій і компетентностей фрахівця шляхом обґрунтування сучасних практико- і суб'єктно-орієнтованих ідей, принципів, методик, технологій і засобів проєктування та моделювання результатів освіти в категоріях «професійні компетенції», «профресійна компетентність» і «фрахова компетентність» [25, с. 84].

Для уникнення суб'єктивізму в розумінні змісту та суті поняття «компетентність» і визначення наукових засад його класифікації науковці виокремлюють провідні характеристики компетентності фрахівця: багатогранність видів компетентності; багатокомпонентність; багатовимірність; міждисциплінарність; різнофункціональність; суб'єктивність [26, с. 51-52].

Вважаємо, що основною ідеєю компетентнісного підходу в розвитку професійної компетентності організаторів МПЗ у системі післядипломної освіти $€$ ідея цілеспрямованого ії контекстного розвитку в діяльнісному аспекті в суб'єкта військово-профресійної діяльності, коли вона стає новою системною контекстною якістю і являє собою комплекс фрахових здатностей, які забезпечують реалізацію основних функцій як суб'єкта військово-професійної діяльності.

Отже, компетентнісний підхід безпосередньо пов'язаний із суб'єктно-діяльнісним підходом, провідною ідеєю якого є уявлення про діяльність, у процесі реалізації якої суб'єкт розв'язує різноманітні завдання [29]. Проблему, пов'язану з діяльністю людини, досліджували вітчизняні та закордонні вчені: Л. Виготський, І. Зязюн, О. Леонтьєв, А. Маслоу, С. Рубінштейн та ін. Так, у розробленій О. Леонтьєвим концепції розвитку психіки категорія «діяльність» посідає важливе місце і лежить в основі визначення суті активності людини. Істотною характеристикою діяльності є вмотивованість. С. Рубінштейн зазначав, що «усяка дія виходить із мотиву» [18, с. 187]. О. Лєонтьєв стверджував, що «діяльності без мотиву не буває» [10, с. 153], тобто діяльність пов'язана з її мотивами. Науковцями також встановлено, що між навчанням i розвитком людини стоїть поняття «діяльність». Особистісні аспекти професійного становлення фрормуються завдяки «діяльнісним фрормам».

Проблему суб'єктно-діяльнісного підходу та суб'єктності також досліджувати такі українські науковці, як Г. Балл, І. Бех, І. Зязюн, В. Осьодло, В. Татенко, В. Ягупов та ін.

Отже, реалізація суб'єктно-діяльнісного підходу до розвитку профресійної компетентності організаторів МПЗ має здійснюватися через всі види їхньої діяльності, що характеризуються відповідною сукупністю педагогічних завдань: проєктування навчально-виховного процесу; дидактичне, матеріально-технічне і методичне забезпечення педагогічного процесу, організацію і здійснення пізнавальної й навчальної діяльності слухачів; діагностування професійного розвитку слухача як майбутнього організатора МПЗ та ін.

На думку В. Ягупова, застосування суб'єктного підходу полягатиме в реалізації у слухачів їхніх суб'єктних проявів. Зокрема, в організаторів МПЗ це: усвідомлення необхідності розвитку професійної та фрахової компетентностей для становлення суб'єктом військово-професійної діяльності; усвідомлення необхідності профресійного та, найголовніше, фрахового вдосконалення як організатора МПЗ, зростання й реалізації кар'єрних перспектив; усвідомлення необхідності здобуття післядипломної професійної освіти для забезпечення своєї професійної мобільності та подолання вікових і профресійних криз; здатність професійно визначати свої фрахові потреби й шукати оптимальні шляхи їх вирішення; свідома саморегуляція і самодетермінація своєї поведінки й діяльності в системі післядипломної освіти як її суб'єкта; свідомий вибір тієї чи іншої суб'єктної позиції в навчальному процесі; намагання внести свій життєвий, а інколи і профресійний досвід у процес навчання; свідомий вибір організаційної фоорми здобуття військово-професійної освіти тощо [25, с. 2-3].

Отже, реалізація суб'єктно-діяльнісного підходу в інтеграції з вимогами інших методологічних підходів у нашому дослідженні полягає в розвитку в організаторів МПЗ професійної суб'єктності, що в певному контексті співвідноситься 3 діалектичним пізнанням військово-професійної сорери та свідомим визначенням свого місця в ній. Для реалізації їхніх вимог доцільно обґрунтувати відповідні педагогічні умови, аналізу яких присвячені праці О. Андреєва, С. Батишева, В. Бєлікова, Б. Гершунського, І. Зязюна, А. Литвина, А. Найна, О. Пєхоти, І. Підласого, В. Радкевича, В. Ягупова й інших дослідників. Проведений аналіз наукових праць вказує на те, що поняття «педагогічна умова» поширене в сучасних педагогічних дослідженнях. Це пов'язано, як показує аналіз наукових джерел вищезазначених науковців, з їхньою практичною значущістю, спрямованістю на покращення профресійної підготовки фахівців. Результати нашого аналізу дозволяють стверджувати, що більшість авторів ставлять за мету виділення, теоретичне обґрунтування й експериментальну апробацію комплексу педагогічних умов, які сприяють розв'язанню конкретного наукового завдання.

Категорія «умова» $€$ загальнонауковою, нами використовується у фрілософському та педагогічному аспектах. У фрілософрії умови - певні обставини, які визначають ті чи інші результати, настання яких перешкоджає одним процесам чи явищам і сприяє іншим. Важливим є те, що умови розглядаються щодо існування, фрункціонування і розвитку того чи іншого предмета, явища, події, стану. Водночас більшість педагогічних словників і енциклопедій не містять дефініцію педагогічних 
умов. У загальному аспекті під умовами науковці розуміють сукупність певних причин, обставин, наявність певних об'єктів, які впливають на фрункціонування досліджуваного явища [11].

В. Бєліков щодо поняття «педагогічні умови» визначає такі ознаки: 1) сукупність зовнішніх об'єктів освітнього середовища, у певних відносинах 3 якими перебуває предмет дослідження; 2) сукупність внутрішніх особливостей (станів, якостей) предмета дослідження, від яких тією чи іншою мірою залежить вирішення проблеми; 3) сукупність зовнішніх об'єктів і внутрішніх особливостей, що визначає існування, функціонування і розвиток предмета дослідження (ефективне розв'язання поставленої проблеми) [2, с. 235].

«Педагогічні умови - один із компонентів педагогічної системи, який відображає сукупність можливостей освітнього та матеріально-просторового середовища, які впливають на особистісний і процесуальний аспекти даної системи та забезпечують її ефективне фрункціонування і розвиток» [8].

А. Литвин під педагогічними умовами розуміє комплекс спеціально спроєктованих генеральних чинників впливу на зовнішні та внутрішні обставини навчально-виховного процесу й особистісні параметри всіх його учасників. Вони забезпечують цілісність навчання та виховання в інформаційноосвітньому середовищі навчального закладу відповідно до вимог суспільства та запитів ринку праці, сприяють усебічному гармонійному розвитку особистості та створюють сприятливі можливості для виявлення її задатків, урахування потреб і фрормування загальнолюдських і професійно важливих якостей, ключових кваліфрікацій, загальних і профресійних компетенцій [11, с. 28-29].

Ураховуючи теоретичну та практичну значущість педагогічних умов для вивчення педагогічних явищ, дослідники їх співвідносять із певною педагогічною дійсністю. Оскільки в педагогічній теорії педагогічні явища різними дослідниками інтерпретуються по-різному, то існують різні класифрікації педагогічних умов. Наприклад, О. Галкіна виокремлює три групи педагогічних умов: «умовапередумова», «умова-обстановка» й «умовавимога», які відповідно проявляються на інституціональному, управлінському та технічному рівнях [6]. Суттєвим недоліком цієї класифрікації $€$ те, що немає суб'єкта навчальної діяльності, а є тільки суб'єкт управління та педагогічної діяльності.

Існують й інші підходи до класифікації педагогічних і організаційно-педагогічних умов розв'язання педагогічних проблем і завдань. Наприклад, серед педагогічних умов розрізняють дидактичні, психолого-педагогічні, організаційно-педагогічні та соціально-педагогічні умови. Проблема розвитку професійної компетентності організаторів МПЗ багато в чому залежить від успішного функціонування як цілої педагогічної системи, так і всіх її елементів, серед яких особливе місце посідають її суб'єкти. У зв'язку із цим вважаємо за необхідне розглядати саме організаційно-педагогічні умови вирішення поставленого в нашому дослідженні педагогічного завдання.

Погоджуємося 3 позицією А. Литвина, який зазначає, що організаційно-педагогічні умови впливають на весь навчальний процес, дозволяють ефрективно керувати, здійснювати цей процес відповідно до завдань із застосуванням обраних форм, методів, прийомів, сукупності положень, дотримання яких забезпечує досягнення поставленої педагогічної мети. Він слушно наголошує, що основною функцією організаційно-педагогічних умов $є$ організація заходів і обставин, які забезпечують цілеспрямоване, плановане управління розвитком педагогічного процесу. До організаційнопедагогічних умов А. Литвин відносить такі: якісне планування освітнього процесу; відбір і структурування змісту; дотримання чіткої послідовності вивчення дисциплін; проведення різнопланових практик, поєднання різних орорм організації навчання, використання сучасних педагогічних технологій; залучення тих, хто вчиться, до самостійної, дослідно-пошукової діяльності; запровадження інноваційної системи контролю знань і вмінь майбутніх фрахівців [11, с. 45-46].

Аналіз наукових підходів до визначення поняття «організаційно-педагогічні умови» дає змогу зробити висновок про те, що під організаційно-педагогічними умовами розвитку професійної компетентності організаторів МПЗ варто розуміти сукупність необхідних і достатніх системних організаційних і педагогічних обставин і чинників у системі післядипломної освіти, які забезпечують найбільш сприятливе педагогічне середовище для розвитку професійної компетентності організаторів МПЗ у системі післядипломної освіти.

Отже, професійна компетентність організаторів МПЗ розвивається на основі положень системного, контекстного, компетентнісного та суб'єктнодіяльнісного підходів.

Для забезпечення цілеспрямованого розвитку професійної компетентності організаторів МПЗ варто обґрунтувати педагогічні умови, які мають створювати педагогічну систему в Національному університеті оборони України та стимулювати всіх суб'єктів навчально-виховного процесу (насамперед заступників командирів військових частин та підрозділів із морально-психологічного забезпечення) до цілеспрямованого розвитку профресійної компетентності слухачів у процесі здобуття оперативно-тактичної освіти. Для цього мають бути обґрунтовані як організаційно-педагогічні, так і методичні умови [25].

Отже, варто визначити педагогічні умови, які доцільно цілеспрямовано створювати та підтримувати для педагогічного забезпечення системного 
розвитку профресійної компетентності майбутніх організаторів МПЗ, що будуть проходити навчання в Національному університеті оборони України.

Перша педагогічна умова. Насамперед треба створити професійно орієнтоване навчальне середовище в Національному університеті оборони України, у якому, з одного боку, наявні всі фрормальні організаційно-педагогічні умови для розвитку їхньої профресійної компетентності, а 3 іншого - саме професійно орієнтоване навчальне середовище має стимулювати, підштовхувати, а інколи і «провокувати» слухачів до розвитку своєї професійної компетентності. Серед них обов'язковою умовою $€$ навчально-методичне забезпечення вивчення психолого-педагогічних, гуманітарних і військово-спеціальних дисциплін, орієнтованих на специфріку роду військ, де організатор МПз буде виконувати свої службові обов'язки. Зміст вказаних дисциплін необхідно безпосередньо спрямовувати на розвиток професійної компетентності організаторів МПЗ. Вивчення цих дисциплін і навчально-методичне забезпечення має обов'язково включати:

- чітку цільову настанову, яка має бути зрозумілою самим слухачам і мотиваційно насиченою й орієнтованою для них;

- змістовну частину, що має відповідати майбутнім фрункціям, які передбачені службовими обов'язками організаторів МПЗ, також обов'язково необхідно враховувати специфіку роду військ і майбутнє посадове призначення, забезпечувати розвиток професійної компетентності як суб'єктів оперативно-тактичної ланки управління;

- методичну частину, яка має містити зрозумілі та зручні методи, методики, технології та засоби вивчення слухачами психолого-педагогічних, гуманітарних і військово-спеціальних дисциплін; серед них обов'язково мають бути такі, які дають можливість реалізувати самовдосконалення слухачів у навчальній діяльності, основні зусилля зосередити безпосередньо на вивченні моральнопсихологічного забезпечення як основного предмета навчання слухачів;

- профресійна спрямованість - наявність професійно орієнтованого навчального матеріалу, 3 використанням досвіду проведення антитерористичної операції й операції Об'єднаних сил, який має корелюватися 3 майбутньою профресійною діяльністю випускників оперативно-тактичного фракультету НУОУ;

- наявність завдань гуманітарного характеру різної складності для самостійної роботи слухачів - від типових і шаблонних до нестандартних і комплексних, які поступово розвивають їхню професійну компетентність як організаторів МПЗ і суб'єктів оперативно-тактичної ланки управління;

- бібліографрічна забезпеченість - це наявність списку основної та додаткової літератури, закордонної також, за використання якого слухачі можуть опановувати програмний матеріал, а також вдосконалювати свої професійні здатності, розвивати профресійну компетентність, розширяти свій професійний кругозір;

- створення сприятливих організаційно-побутових умов для самостійної роботи слухачів як у навчальний, так і в позанавчальний час.

Друга педагогічна умова стосується змісту професійної підготовки слухачів, який, з одного боку, має враховувати цілі, завдання, принципи та специоріку їхньої майбутньої професійної діяльності на оперативно-тактичній ланці, а з іншого безпосередньо створити когнітивну основу розвитку їхньої профресійної компетентності як майбутніх суб'єктів цієї ланки. Зміст навчального матеріалу та методика його вивчення слухачами має стимулювати фрормування, розвиток і вдосконалення як наявних, так і нових прийомів і форм розвитку профресійної компетентності.

Третя педагогічна умова - це профресійно орієнтовані методики та дидактичні технології проведення навчальних заходів зі слухачами, які мають цілеспрямовано стимулювати розвиток їхньої професійної компетентності, з урахуванням військово-професійного та досвіду проведення антитерористичної і операції Об'єднаних сил, їхніх вікових особливостей, майбутніх кар'єрних перспектив офріцерів структур МПЗ також. Найголовніше в методичній складовій частині - обов'язково треба передбачувати розвиток специфрічних фрорм і способів, рис і якостей процесів, які стимулюють розвиток профресійної компетентності організаторів МПЗ на оперативно-тактичній ланці управління.

Четверта педагогічна умова - це мотивування організаторів МПЗ у розвитку та саморозвитку їхньої професійної компетентності.

Дослідження Л. Виготського, О. Леонтьєва, А. Маслоу, С. Рубінштейна, П. Якобсона й інших науковців вказують на те, що мотивація $€$ основою активності людини в діяльності.

Мотивація - це система уявлень та переконань, почуттів і переживань, у яких виражаються матеріальні й духовні, природні й культурні потреби людини, а усвідомлення потреб і предметів, якими вони задовольняються, утворює загальний механізм мотивування діяльності [6, с. 528]. Отже, мотивуванням прийнято називати процес спонукання особистості до діяльності для досягнення поставлених цілей. На думку О. Леонтьєва, співвідношення мотивів, потреб, інтересів і цілей утворює особистісний смисл будь-якої діяльності [6, с. 528].

3 урахуванням настанов педагогічної та психологічної теорії вважаємо, що для розвитку професійної компетентністі в організаторів МПЗ потрібно сорормувати такі мотиви діяльності: усвідомлення потреби в суспільно значущій службовій діяль- 
ності, яка спрямована на організацію МПЗ, як одного з основних видів усебічного забезпечення; потреба в розвитку професійних якостей і здатностей; потреба в пізнанні психолого-педагогічних наук, гуманітарних і військово-спеціальних дисциплін; потреба в самоствердженні як творчого суб'єкта у службовій діяльності.

Оскільки мотиваційна сорера організаторів МПЗ $€$ динамічною, то позитивні мотиви можуть виникати як під час службової діяльності, так і у процесі самовдосконалення. Отже, реалізація цієї умови розвитку їхньої професійної компетентності засвідчує задоволення таких особистісних і професійних потреб, як підвищення професійного рівня організаторів МПЗ, удосконалення їхніх професійно важливих якостей, а також їхнього особистісного і професійного самоствердження у професійному середовищі.

Висновки. Отже, нами встановлено, що процес розвитку професійної компетентності в організаторів МПЗ під час здобуття ними оперативно-тактичної освіти визначатиметься низкою організаційнопедагогічних умов, що являють собою системну сукупність необхідних і достатніх чинників і обставин. 3 одного боку, вона забезпечує найбільш сприятливе середовище для ефективного функціонування педагогічної моделі розвитку профресійної компетентності, а з іншого - цілеспрямований розвиток цієї компетентності. Узагальненою методологічною основою дослідження проблем розвитку професійної компетентності організаторів МПЗ на етапі оперативно-тактичної підготовки $€$ положення системного, контекстного, компетентнісного та субєктно-діяльнісного підходів, які перебувають у підпорядкуванні та тісній взаємодії. Такий процес буде результативним, якщо йому сприятимуть такі організаційно-педагогічні умови, які забезпечуватимуть поєднання організаційних форм підготовки офріцерів структур МПЗ на базі НУОУ, урахування актуального стану розвиненості професійної компетентності, фрункціонування компетентнісної моделі розвитку профресійної компетентності, урахування стану потреб і запитів фрахівців МПЗ під час фрормування навчального змісту, які задовольнять їхні потреби у профресійному зростанні та становленні.

Подальші перспективи в цьому напрямі: педагогічне моделювання розвитку професійного мислення офріцерів структур морально-психологічного забезпечення на етапі оперативно-тактичної підготовки.

\section{БІБЛІОГРАФІЧНИЙ СПИСОК:}

1. Академічний тлумачний словник української мови. URL: http://sum.in.ua/s (дата звернення: 15.09.2019).

2. Беликов В. Философия образования личности: Деятельностный аспект : монография. Москва : Гуманитарный издат. центр «Владос», 2004. 357 с.
3. Вербицкий А. Компетентностный подход и теория контекстного обучения : материалы к 4-му заседанию методологического семинара 16 ноября 2004 г. Москва : ИЦПКПС, 2004. 84 с.

4. Вітченко А., Осьодло В. Педагогіка вищої військової школи : підручник. Київ : НУОУ ім. Іван Черняховського, 2017. 504 с.

5. Волкова В., Денисов А. Теория систем и системный анализ : учебник для академического бакалавриата. Москва : Юрайт, 2014. 616 с.

6. Галкина О. Роль и место понятия «организационно-педагогические условия» в терминологическом аппарате педагогической науки : дис. ... канд. пед. наук: 13.00.01. Самара, 2009. 187 с.

7. Зеер Э., Сыманюк Э. Компетентностный поход к модернизации профессионального образования. Высшее образование в России. 2005. № 4. С. 23-32.

8. Ипполитова Н., Стерхова Н. Анализ понятия «педагогические условия»: сущность, классификация. General and Professional Education. 2012. № 1. C. 8-14.

9. Крисюк С. Розвиток післядипломної освіти педагогічних кадрів в Україні (1917-1995 рр.) : монограсрія. Львів : ЛОНМІО, 1997. 206 с.

10. Леонтьев А. Деятельность. Сознание. Личность. Москва : Политиздат, 1977. 304 с.

11. Литвин А. Методологічні засади поняття «педагогічні умови» : на допомогу здобувачам наукового ступеня. Львів : СПОЛОМ, 2014. 76 с.

12. Михнюк М. Наукові підходи до розвитку професійної культури викладачів спеціальних дисциплін будівельного профілю. URL: http://irbis-nbuv.gov.ua/cgibin/irbis_nbuv/cgiirbis_64. exe?C21COM=2\&I21DBN=UJRN\&P21DBN=UJRN\& IMAGE_FILE_DOWNLOAD=1\&Image_file_name=PDF/ Nvipto_2015_9_5.pdf (дата звернення: 25.08.2019).

13. Олійник В. Наукові основи управління підвищення кваліфрікації педагогічних працівників профртехосвіти : монографрія. Київ : Міленіум, 2003. 594 с.

14. Педагогика : большая современная энциклопедия / сост. Е.С. Рапацевич. Минск : Современное слово, 2005. 720 с.

15. Підготовка майбутнього вчителя до впровадження педагогічних технологій : навчальний посібник / О. Пєхота та ін. ; за ред. І. Зязюна, О. Пєхоти. Київ : А. С. К., 2003. 240 с.

16. Платонов К. Структура и развитие личности / под ред. А. Глоточкина. Москва : Наука, 1986. 254 с.

17. Дубасенюк О. Професійна педагогічна освіта: компетентнісний підхід : монограсрія. Житомир : вид-во ЖДУ ім. Івана Франка, 2011. 412 с.

18. Рубинштейн С. Проблемы обшей психологи. Москва : Педагогика, 1973. 423 с.

19. Сластенин В. Педагогика: инновационная деятельность. Москва : Магистр, 1997. 224 с.

20. Словник-довідник 3 професійної педагогіки / за ред. А. Семенової. Одеса : Пальміра, 2006. 364 с.

21. Філософський енциклопедичний словник / за ред. В. Шнкарука та ін. Київ : Абрис, 2002. 750 с.

22. Филососский энциклопедический словарь / под ред. Л. Ильичева и др. Москва : Сов. энцикл., 1983. $840 \mathrm{c}$.

23. Шемчук В. Педагогічні умови розвитку управлінського мислення майбутніх магістрів військового 
управління в системі післядипломної освіти : дис. ... канд. пед. наук: 13.00.04. Київ, 2012. 286 с.

24. Ягупов В. Забезпечення якості профресійно-технічноїосвіти: суб'єктнийпідхід. URL:http://lib.iitta.gov.ua/ 7226/1/ЗАБЕЗПЕЧЕННЯ_ЯКОСТІ_ПРОФЕСІЙНО.pdf (дата звернення: 12.09.2019).

25. Ягупов В. Методологические требования компетентностного подхода в профессиональном образовании. Вища освіти України : теоретичний і науковометодичний часопис. 2013. № 1. Додаток 1 : Педагогіка вищої школи : методологія, теорія, технології. С. 82-85.

26. Ягупов В. Провідні методологічні характеристики основних видів компетентності майбутніх фрахівців, що формуються в системі професійно-технічної освіти. Модернізація профресійної освіти і навчання : збірник наукових праць. Київ : ІПТО НАПН України, 2012. Вип. 2. С. 45-59.
27. Ягупов В. Профресійний розвиток особистості фрахівця: поняття, зміст та особливості. Наукові записки НаУКМА. Педагогічні, психологічні науки та соціальна робота. 2015. Т. 175. С. 22-28. URL: http://nbuv.gov.ua/UJRN/NaUKMApp_2015_ 175_4 (дата звернення: 02.09.2019).

28. Ягупов В. Управлінська культура і компетентність керівників як системна психолого-педагогічна проблема. Збірник наукових праць Національної академії Державної прикордонної служби України. Серія «Педагогічні та психологічні науки» / гол. ред. В. Райко. Хмельницький : Вид-во НАДПСУ, 2013. № 4 (69). С. 291-301.

29. Ягупов В. Формирование и развитие профессиональной субъектности офицеров. Известия Российской академии образования. 2013. № 1. C. 74-83. 